\title{
Treatment of severe hypertension and hypertensive emergencies with intravenous clonidine hydrochloride
}

\author{
ANDREAS P. NiARChOS* \\ M.D.
}

\author{
ARUN K. BAKSI* \\ M.B., B.S., M.R.C.P.
}

Whiston Hospital, Prescot, Lancashire

\begin{abstract}
Summary
Eleven severely hypertensive patients, median age 54 years, were treated with intravenous (i.v.) clonidine hydrochloride (Catapres). In nine there were lifethreatening complications: severe left ventricular failure (LVF), hypertensive encephalopathy, cerebral haemorrhage, dissecting aortic aneurysm, renal failure, and severe epistaxis. In two patients there was pronounced, but uncomplicated, elevation of blood

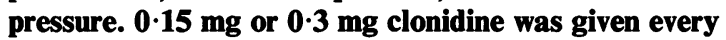
$40 \mathrm{~min}$ with electrocardiographic (ECG) monitoring. The mean systolic and diastolic blood pressures in the eleven patients were respectively 266 and $165 \mathrm{mmHg}$ before treatment falling to 165 and $109 \mathrm{mmHg}$ after treatment $(P<0.001)$. The mean decrease in heart rate was 26 beats $/ \mathrm{min}(P<0.001)$. Doses of clonidine required for control ranged from $0.15 \mathrm{mg}$ (one ampoule) to $0.9 \mathrm{mg}$ (mean $0.56 \mathrm{mg}$ ), although one patient received a total of $0.9 \mathrm{mg}$ without an adequate response. The presenting condition caused the eventual death of two patients. There were no serious side effects, except for one transient episode of sino-atrial heart block. It is concluded that clonidine is effective and safe in the treatment of hypertensive emergencies.
\end{abstract}

\section{Introduction}

Clonidine hydrochloride (Catapres) is an imidazoline derivative which lowers blood pressure when administered in microgram $(\mu \mathrm{g})$ doses. (Conolly, 1969). To date, a number of publications have shown clonidine to be an effective oral treatment in mild, benign or moderate hypertension (Gifford, 1969; Kellett \& Hamilton, 1970; MacDougall et al., 1970), in severe hypertension (Raftos, 1969; MacDougall et al., 1970) and hypertension in pregnancy (Turnbull \& Ahmad, 1969; Johnston \& Aickin, 1971). In other studies the drug has compared well with methyldopa in various clinical trials. Thus, Finnerty (1969) concluded that the fall in arterial

\footnotetext{
* Present address: Royal Southern Hospital, Caryl Street Liverpool 8.

Address for correspondence: Dr A. P. Niarchos, M. D., Medical Registrar, Royal Southern Hospital, Caryl Street, Liverpool 8.
}

pressure with chlorothalidone plus clonidine was slightly greater than with chlorothalidone and methyldopa. Conolly, Paterson \& Dollery (1969) found close resemblance in the efficacy and side effects between clonidine and methyldopa. Amery et al. (1970) concluded that the diastolic morning blood pressure could be reduced to $95 \mathrm{mmHg}$ or below in significantly more patients with clonidine than with methyldopa, but clonidine had more side effects. In a comparison with guanethidine, clonidine had the same or often better hypotensive effect (Hoobler \& Sagastume, 1969). Thiazide diuretics enhance clonidine's hypotensive effect (Onesti et al., 1969; Gifford, 1969). Intravenous clonidine has been used in haemodynamic studies in normotensive subjects and patients with uncomplicated hypertension (Barnett \& Cantor, 1968; Finnerty, 1969; Muir, Burton \& Lawrie, 1969; McRaven et al., 1971), and in the treatment of hypertensive emergencies, where it proved very effective and favourably comparable with reserpine, guanethidine, hydralazine and alpha-methyldopa, since it caused the greatest decrease in blood pressure 1 and $2 \mathrm{hr}$ after drug administration (Onesti et al., 1971). However, in their paper Onesti et al., gave no details regarding the nature, clinical condition of the patients and the outcome of the emergencies treated. Since no ideal drug for the treatment of hypertensive crises yet exists we thought that further evaluation of i.v. clonidine might be useful. We report here our experience with i.v. clonidine in patients with severe hypertension and life-threatening hypertensive emergencies.

\section{Patients and methods}

Five male and six female patients who were considered to require urgent reduction of blood pressure were treated with i.v. clonidine using a standardized regime (see below). Ages ranged from 25 to 70 years, median 54 years. Six had essential and five renal hypertension of duration 1 to 12 years, this being unknown in two. Three had received no previous treatment for hypertension. In two there was no frank hypertensive crisis but they were in- 
TABLE 1. Clinical details

\begin{tabular}{|c|c|c|c|c|c|c|c|c|c|c|}
\hline \multirow{2}{*}{$\begin{array}{l}\text { Case } \\
\text { no. }\end{array}$} & \multirow[b]{2}{*}{ Sex } & \multirow[b]{2}{*}{ Age } & \multirow{2}{*}{$\begin{array}{c}\text { Type of } \\
\text { hypertension }\end{array}$} & \multirow{2}{*}{$\begin{array}{l}\text { Duration } \\
\text { (years) }\end{array}$} & \multirow{2}{*}{$\begin{array}{l}\text { Previous } \\
\text { treatment }\end{array}$} & \multirow{2}{*}{$\begin{array}{c}\text { BP before } \\
\text { treatment } \\
(\mathrm{mmHg})\end{array}$} & \multirow{2}{*}{$\begin{array}{l}\text { Hypertensive } \\
\text { emergency }\end{array}$} & \multirow{2}{*}{$\begin{array}{l}\text { Fundi } \\
\text { grade }\end{array}$} & \multicolumn{2}{|c|}{ LV hypertrophy } \\
\hline & & & & & & & & & ECG & X-ray \\
\hline 1 & $\mathbf{F}$ & 46 & Essential & 1 & No & $270 / 180$ & - & II & + & + \\
\hline 2 & $\mathbf{F}$ & 64 & Essential & 12 & Yes & $290 / 180$ & $\begin{array}{l}\text { Cerebral } \\
\text { haemorrhage. } \\
\text { Mild LVF }\end{array}$ & III-IV & $+t+$ & ND \\
\hline 3 & $\mathbf{M}$ & 47 & Essential & 3 & Yes & $280 / 180$ & $\begin{array}{l}\text { Encephalopathy } \\
\text { Mild LVF }\end{array}$ & II-III & $++t$ & $+t+$ \\
\hline 4 & $\mathbf{F}$ & 24 & Renal & 9 & Yes & $240 / 150$ & - & II & + & ++ \\
\hline 5 & $\mathbf{M}$ & 70 & Essential & 16 & Yes & $200 / 150$ & Severe epistaxis & II & ++ & ++ \\
\hline 6 & $\mathbf{F}$ & 70 & $\begin{array}{l}\text { Essential, } \\
\text { diabetes } \\
\text { mellitus }\end{array}$ & 12 & Yes & $270 / 160$ & Encephalopathy & II-III & $+t+$ & ++ \\
\hline 7 & $\mathbf{M}$ & 56 & Renal & 7 & Yes & $290 / 170$ & Severe LVF & II-III & $++t$ & ++ \\
\hline 8 & $\mathbf{M}$ & 48 & Essential & Unknown & No & $280 / 170$ & $\begin{array}{l}\text { Dissecting aortic } \\
\text { aneurysm }\end{array}$ & I & ++ & $?$ \\
\hline 9 & $\mathbf{F}$ & 54 & Renal & Unknown & No & $310 / 170$ & $\begin{array}{l}\text { Severe LVF, renal } \\
\text { failure }\end{array}$ & II & ++ & + \\
\hline 10 & $\mathbf{M}$ & 69 & Essential & 6 & Yes & $250 / 140$ & Encephalopathy & II & ++ & + \\
\hline 11 & F & 34 & Renal & 7 & Yes & $250 / 150$ & Encephalopathy & III-IV & ++ & + \\
\hline
\end{tabular}

+ , slight; ++ , moderate; +++ , marked; ND, not done.

cluded because of very high diastolic pressure associated with severe headache. The blood pressure on admission, nature of hypertensive emergency, clinical and other findings are given in Tables 1 and 2.

As soon as the diagnosis and decision to treat urgently was made, the level of blood pressure recording was confirmed by two independent observers. A chest radiograph was obtained and blood taken for serum creatinine, urea, electrolytes and routine haematology. A 12-lead ECG was recorded initially and monitored throughout treatment.

All patients had a slow continuous i.v. drip of $5 \%$ dextrose, nine received $0.15 \mathrm{mg}$ (one ampoule) of clonidine and two $0.3 \mathrm{mg}$, via the injection rubber of the giving set, every $\mathbf{4 0} \mathrm{min}$ until the diastolic blood pressure had fallen to $120 \mathrm{mmHg}$ or below, a level decided by us to represent satisfactory control in these circumstances. As experience was gained, however, and no serious unwanted effects were observed, some patients received additional injections. Oral clonidine $\mathbf{0 . 2} \mathrm{mg}$ four times daily was

TABLE 2. Main signs and symptoms

\begin{tabular}{lc}
\hline & $\begin{array}{c}\text { No. } \\
\text { observed }\end{array}$ \\
\hline Severe headache & 4 \\
Hemi- or monoplegia & 3 \\
Aphasia or dysphasia & 4 \\
Unconscious & 2 \\
Orthopnoea-cyanosis & 2 \\
Convulsions & 3 \\
Oliguria-azotaemia & 1 \\
Epistaxis & 1 \\
\hline
\end{tabular}

started when the blood pressure was controlled and the i.v. treatment discontinued.

Blood pressures were recorded before and every $10 \mathrm{~min}$ during treatment by one of us (A.P.N.) using a mercury sphygmomanometer (Pickering, 1968). By agreement, the first Korotkow sound corresponded to the systolic blood pressure and the disappearance of sound to the diastolic. The heart rate was taken from the ECG at the time of blood pressure measurement. Conscious patients were tilted to the $45^{\circ}$ head-up position. A resuscitation trolley with the appropriate drugs, defibrillator and pacemaker were at hand. No other drugs were given during treatment with the exception of three patients who received frusemide and digoxin and one phenytoin.

Fluid balance charts were carefully kept and serum creatinine and blood urea were estimated shortly after treatment.

\section{Results}

\section{Blood pressure and heart rate changes}

In all but one patient the blood pressure fell to $120 \mathrm{mmHg}$ diastolic or below (Table 3). The mean systolic and diastolic pressures before treatment were 266 and $165 \mathrm{mmHg}$ respectively falling with treatment to 165 systolic $(t=10.43, P<0.001)$ and 109 diastolic $(t=11.00, P<0.001)$. These changes are highly significant. Figure 1 shows the mean response of blood pressure and heart rate after injection of $0.15 \mathrm{mg}$ clonidine at $40 \mathrm{~min}$ intervals and Fig. 2 the individual overall responses. The reduction in blood pressure was smooth in all cases without sudden pressure variations and there were no hypotensive episodes, even when injections of $0.3 \mathrm{mg}$ 
TABLE 3. Blood pressures before and during treatment with clonidine i.v.

\begin{tabular}{|c|c|c|c|c|c|c|c|}
\hline \multirow{2}{*}{$\begin{array}{c}\text { Case } \\
\text { no. }\end{array}$} & \multirow{2}{*}{$\begin{array}{l}\text { Before } \\
\text { clonidine }\end{array}$} & \multicolumn{4}{|c|}{ Minutes from start of treatment } & \multirow{2}{*}{$\begin{array}{l}\text { Total i.v. } \\
\text { dose (mg) }\end{array}$} & \multirow[b]{2}{*}{ Outcome } \\
\hline & & 40 & 80 & 120 & 160 & & \\
\hline 1 & $270 / 180$ & $230 / 170$ & $190 / 155$ & $170 / 120$ & OT & 0.45 & Controlled. Survived \\
\hline 2 & $290 / 180$ & $150 / 100$ & OT & OT & OT & $0 \cdot 15$ & Controlled. Died \\
\hline 3 & $280 / 180$ & $260 / 180$ & $220 / 160$ & $210 / 145$ & $200 / 150$ & 0.90 & Not controlled. Survived \\
\hline 4 & $240 / 150$ & $190 / 160$ & $165 / 120$ & $140 / 100$ & OT & 0.45 & Controlled. Survived \\
\hline 5 & $200 / 150$ & $170 / 130$ & $165 / 110$ & $140 / 90$ & OT & 0.45 & Controlled. Survived \\
\hline 6 & $270 / 160$ & $210 / 120$ & $160 / 90$ & OT & OT & $0 \cdot 30$ & Controlled. Survived \\
\hline 7 & $290 / 170$ & $270 / 170$ & $210 / 150$ & $190 / 130$ & $170 / 110$ & 0.60 & Controlled. Survived \\
\hline 8 & $280 / 170$ & $250 / 160$ & $200 / 130$ & $170 / 110$ & OT & 0.45 & Controlled. Died \\
\hline 9 & $310 / 190$ & $260 / 180$ & $220 / 150$ & $180 / 130$ & $160 / 115$ & 0.60 & *Controlled. Survived \\
\hline 10 & $250 / 140$ & $230 / 130$ & $250 / 140$ & $210 / 110$ & OT & 0.90 & †Controlled. Survived \\
\hline 11 & $250 / 150$ & $180 / 140$ & $150 / 120$ & $150 / 110$ & OT & 0.90 & †Controlled. Survived \\
\hline
\end{tabular}

*Diuretic + digoxin in addition. $\uparrow$ Each injection $0.3 \mathrm{mg}$. OT, start of oral treatment at this time.

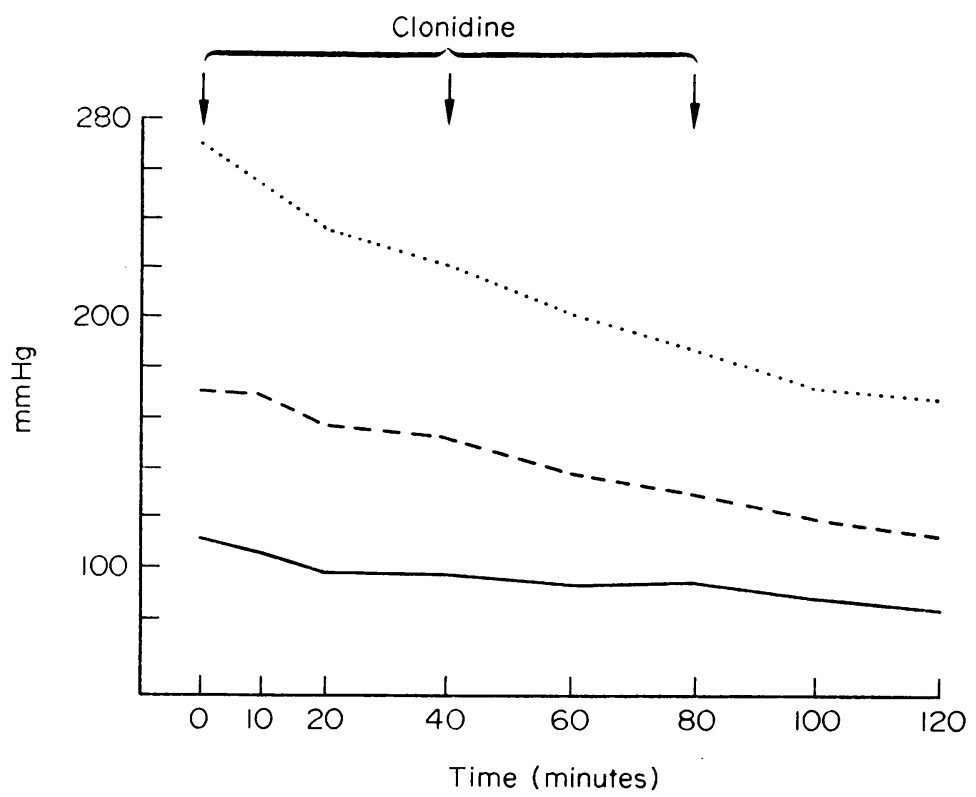

FIG. 1. Changes in mean systolic $(\cdots \cdots)$ and diastolic $(---)$ blood pressures and heart rate $(-)$ during treatment.

were used. There was a greater fall in systolic than diastolic pressure, particularly during the early stages. Heart rate fell initially with less change after subsequent injections (Fig. 3), the overall mean reduction being 26 beats $/ \min (t=8.64, P<0.001)$. In two patients $0.15 \mathrm{mg}$ was adequate to achieve a diastolic pressure of $120 \mathrm{mmHg}$, though further injections were required in the other patients (Tables 3 and 4, Fig. 4). With the exception of one patient who did not reach the desired diastolic level after $0.9 \mathrm{mg}$, the mean dose to achieve this level was $0.56 \mathrm{mg}$.

\section{Outcome and follow-up}

The reduction of blood pressure brought symptomatic improvement in most of the patients. Thus headaches became less severe in all, speech improved in three, and consciousness in one. Convulsions ceased in two. The third was controlled by phenytoin. In case 5, nasal bleeding ceased when the diastolic pressure fell to $120 \mathrm{mmHg}$. Of the eleven patients, two died despite adequate control of blood pressure. Case 2 was admitted with a massive cerebral haemorrhage and died $7 \mathrm{hr}$ later, the diagnosis being confirmed at necropsy. The other patient (case 8) 


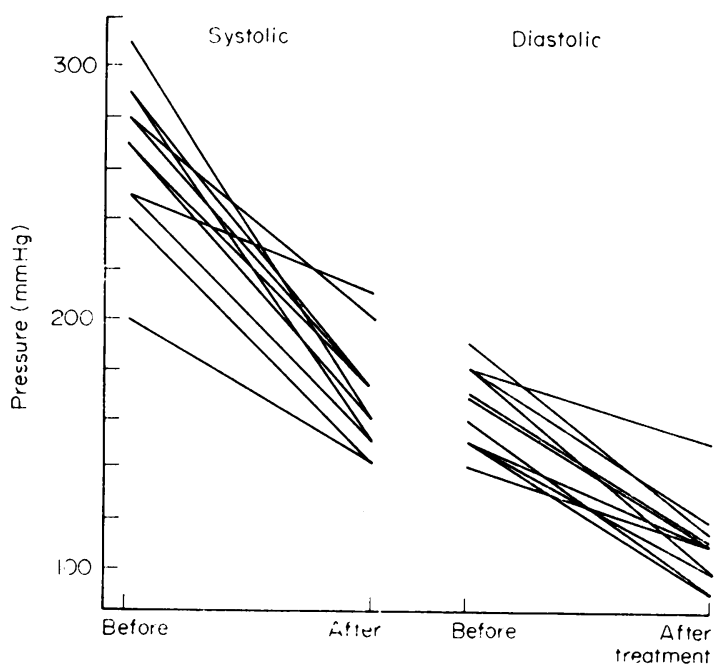

Fig. 2. Systolic and diastolic blood pressures before and after treatment with i.v. clonidine.

\section{Lead II}

(a)

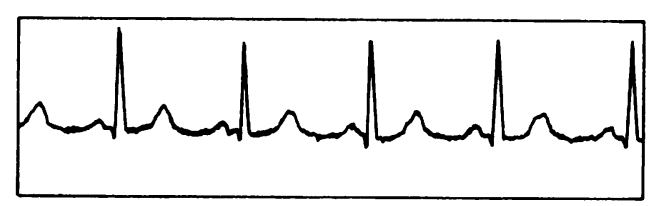

(b)

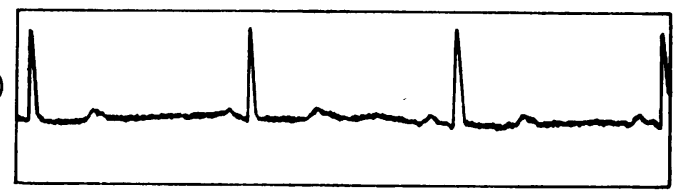

FIG. 3. Case 1. Blood pressure and heart rate before (a) and after (b) i.v. clonidine. a, BP $270 / 180 \mathrm{mmHg}$; b, BP $165 / 120 \mathrm{mmHg}$.

TABLE 4. Dose of clonidine and time required for control of blood pressure in the eleven patients

\begin{tabular}{crccr}
\hline \multirow{2}{*}{$\begin{array}{c}\text { Clonidine } \\
\text { total dose } \\
(\mathrm{mg})\end{array}$} & \multicolumn{3}{c}{ No. of patients } \\
\cline { 2 - 4 } & Total & Controlled controlled & $\begin{array}{c}\text { Not } \\
\text { (min) }\end{array}$ \\
\hline 0.15 & 2 & $2^{*}$ & 9 & 40 \\
& & 2 & & 80 \\
0.45 & 4 & $2^{*}$ & 5 & 120 \\
0.60 & 2 & 3 & 3 & 160 \\
0.90 & 3 & 2 & 1 & 120 \\
Total & 11 & 10 & 1 & - \\
\hline \multicolumn{5}{c}{ * One died. }
\end{tabular}

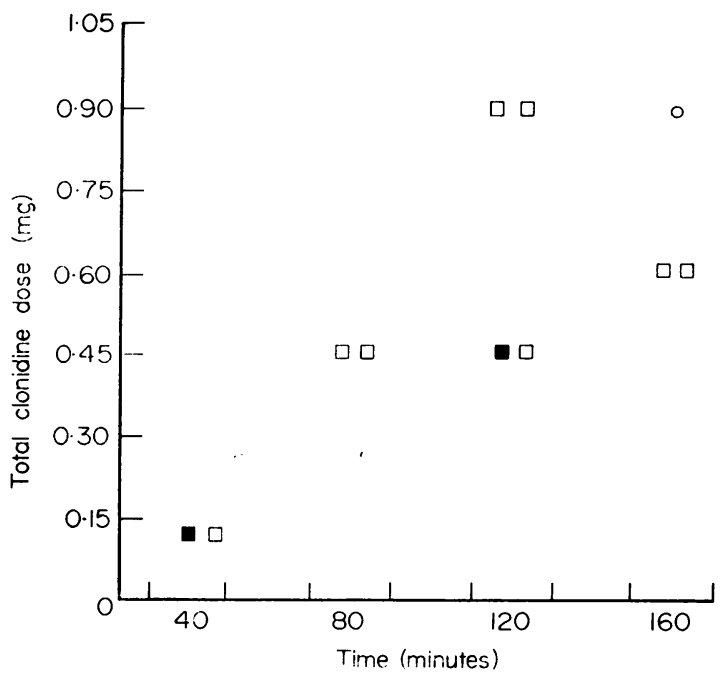

FIg. 4. Dose of clonidine and time required for control of blood pressure in the eleven patients. $\square$, controlled, survived; $\square$, controlled, died; $O$, not controlled, survived.

had a dissecting aortic aneurysm (Fig. 5) and died suddenly on the third day after admission. At necropsy, a tear $1 \mathrm{~cm}$ long was found in the aortic inner wall $3 \mathrm{~cm}$ above the aortic valve, with dissection extending to the common iliac arteries. One patient in renal failure (case 9) needed haemodialysis for 3 days, and one (case 7) underwent left nephrectomy 2 weeks after admission. Case 3 who became resistant to clonidine and pentolinium was eventually controlled using diazoxide.

\section{Side effects}

During the i.v. treatment no serious side effects were observed (Table 5) and most of them were transient. One patient developed a transient sinoatrial heart block. Serial ECGs showed spontaneous reversion to normal sinus rhythm. During the oral treatment drowsiness and dry mouth were common during the first days of treatment.

\section{Fluid balance}

Eight patients had normal fluid balance, two had positive fluid balance due to left ventricular failure which was treated with frusemide, one patient developed positive fluid balance due to acute ventricular and renal failure which were treated with haemodialysis.

\section{Renal function}

The pre-treatment and shortly after treatment values for serum creatinine and blood urea did not differ significantly (Table 6). 


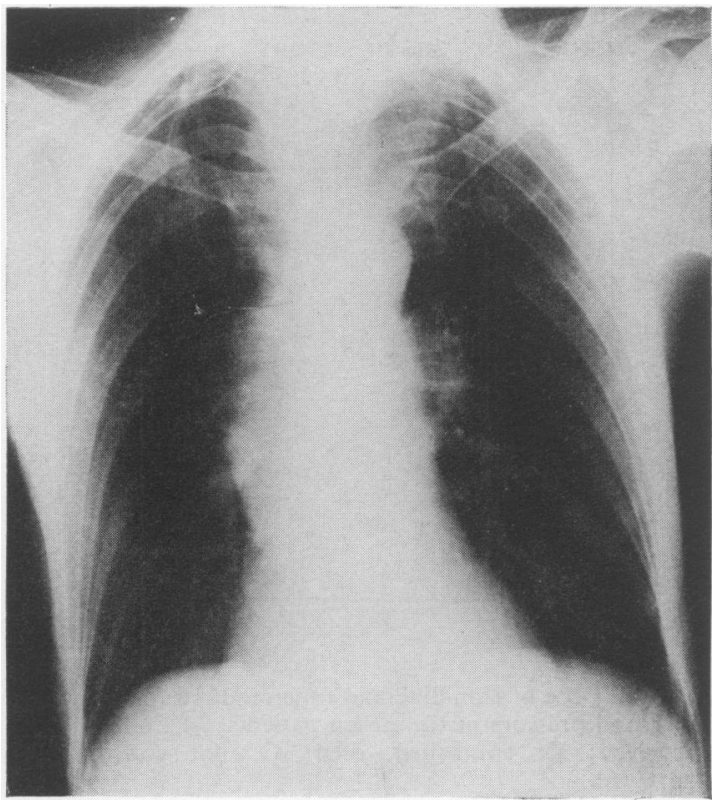

FIG. 5. Case 8. Dissecting aortic aneurysm confirmed by necropsy.

TABLE 5. Side effects during the i.v. treatment

\begin{tabular}{lc}
\hline & $\begin{array}{c}\text { No. } \\
\text { observed }\end{array}$ \\
\hline Sinus arrhythmia & 3 \\
Sinoatrial heart block & 1 \\
$\quad$ (transient) & \\
Dizziness & 2 \\
Sleepiness & 2 \\
Tiredness & 2 \\
Tremor & 1 \\
Over-breathing & 1 \\
\hline
\end{tabular}

\section{Discussion}

This series, though small, showed intravenous clonidine to be very effective in reducing both systolic and diastolic blood pressures in all but one patient. Control was obtained in eight patients within $2 \mathrm{hr}$, and within $2 \mathrm{hr}$ and $40 \mathrm{~min}$ in the remaining two. Although the desired speed of pressure reduction in emergencies is still controversial (Vaamonde, David \& Palmer, 1971) larger and more frequent injections may be more effective. Considering the range of hypertensive emergencies treated (encephalopathy, LVF, renal failure and severe epistaxis), the potency, speed of action, contra-indications and side effects of the currently available hypotensive drugs, clonidine appears to be superior to reserpine, methyldopa, hydralazine and guanethidine, and probably equal to pentolinium. In the doses given,
TABle 6. Renal function tests before and after treatment

\begin{tabular}{cccccc}
\hline & \multicolumn{2}{c}{ Before } & & \multicolumn{2}{c}{ After } \\
\cline { 2 - 3 } \cline { 5 - 6 } Case no. & $\begin{array}{c}\text { Serum } \\
\text { creatinine } \\
(\mathrm{mg} \%)\end{array}$ & $\begin{array}{c}\text { Blood } \\
\text { urea } \\
(\mathrm{mg} \%)\end{array}$ & $\begin{array}{c}\text { Serum } \\
\text { creatinine* } \\
(\mathrm{mg} \%)\end{array}$ & $\begin{array}{c}\text { Blood } \\
\text { urea } \dagger \\
(\mathrm{mg} \%)\end{array}$ \\
\hline 1 & 0.9 & 30 & 1.1 & 32 \\
2 & 0.8 & 40 & & ND & ND \\
$3 \ddagger$ & 1.6 & 46 & 1.2 & 32 \\
4 & 1.0 & 28 & 1.2 & 40 \\
5 & 0.8 & 34 & 1.0 & 38 \\
6 & 1.2 & 46 & 1.2 & 40 \\
$7 \ddagger$ & 1.4 & 60 & 1.1 & 42 \\
8 & 1.3 & 50 & & ND & 46 \\
$9 \ddagger$ & 2.6 & 140 & $1.4 \S$ & $60 \S$ \\
10 & 0.9 & 40 & 1.1 & 36 \\
11 & 1.4 & 48 & 1.0 & 36 \\
Mean & 1.26 & $51 \cdot 1$ & 1.14 & 40.2 \\
\hline
\end{tabular}

* Serum creatinine: mean difference $=-12 \cdot 0, t=$ $1 \cdot 49$, not significant.

ND, not done.

$\dagger$ Blood urea: mean difference $=-0 \cdot 17, t=1 \cdot 07$, not significant

$\ddagger$ Patient received frusemide.

$\S$ Patient had haemodialysis (see text).

however, when compared with trimetaphan, sodium nitroprusside and diazoxide, clonidine appeared to be inferior in speed of action and potency but nevertheless had less serious side effects (Breslin, 1969; Vaamonde et al., 1971). Despite good controlô of blood pressure, the two deaths were inevitable, since both severe cerebral haemorrhage and dissecting aneurysm carry a high mortality.

In no case was a rise in blood pressure seen when clonidine was first given (Finnerty, 1969; Muir et al. 1969; McRaven et al., 1971) nor was there noticeable impairment of renal function. Side effects were not troublesome. The transient sino-atrial heart block in one patient may be due to an increase in vagal tone, such changes in vagal tone have been demonstrated in animals by Robson \& Kaplan (1969) and may contribute to the bradycardia seen in a proportion of patients (Muir et al., 1969; McRaven et al., 1971). Because of this, continuous ECG monitoring is advisable during the i.v. treatment.

The mode of action of clonidine is still uncertain but it can be divided into central, associated with reduced sympathetic tone (Schmitt et al., 1967) together with increased vagal tone (Robson \& Kaplan, 1969; Kobinger \& Walland, 1971), and peripheral, characterized by a reduction in the response of vascular smooth muscle to stimuli (Zaimis \& Hanington, 1969). The hypotension following i.v. clonidine is predominantly due to reduction in cardiac output without a corresponding rise in peripheral resistance (Muir et al., 1969; Onesti et al., 1971). 
We conclude that clonidine is a safe and effective alternative drug for the treatment of severe hypertension and hypertensive emergencies. For the successful treatment of some hypertensive emergencies, however, combination with diuretics, digoxin, anti-convulsants, dialysis or other measures may still be required.

\section{Acknowledgments}

We are very grateful to all consultants who allowed us to treat patients in their care, to Dr J. W. Bell for stimulating discussions, to Mrs P. Pollard for statistical help, and to Miss E. Mooney for typing the manuscript and drawing the figures.

\section{References}

Amery, A., Verstraete, M., Bossaert, H. \& Verstrecken, G. (1970) Hypotensive action and side effects of clonidinechlorothalidone and methyldopa-chlorothalidone in treatment of hypertension. British Medical Journal, 4, 302.

BARNETT, S.J. \& CANTOR, S. (1968) Observations on the hypotensive action of 'Catapres' (St-155) in man. Medical Journal of Australia, 1, 87.

Breslin, D. (1969) Hypertensive crisis. Medical Clinics of North America, 53, 351.

Conolly, M.E. (Ed.) (1969) Catapres in Hypertension, p. 1. Butterworths: London.

Conolly, M.E., Paterson, J.W. \& Dollery, C.T. (1969) A comparative trial of Catapres and methyldopa. In: Catapres in Hypertension (Ed. by M. E. Conolly), p. 167. Butterworths, London.

FinNERTY, F.A. JR (1969) Evaluation of the anti-hypertensive effects of Catapres in man. In: Catapres in Hypertension (Ed. by M. E. Conolly), p. 155. Butterworths: London.

GIFFORD, R.W. (1969) Clonidine in the management of mild hypertension in twenty-two patients. Cleveland Clinic Quarterly, 36, 173.

Hoobler, S.W. \& SAgastume, E. (1969) Long term clinical experience with Catapres; comparison with guanethidine. In: Catapres in Hypertension (Ed. by M. E. Conolly), p. 207. Butterworths: London.

Johnston, C.I. \& AICKIN, D.R. (1971) The control of high blood pressure during labour with clonidine (Catapres). Medical Journal of Australia, 2, 132.
Kellet, R.J. \& Hamilton, M. (1970) The treatment of benign hypertension with clonidine. Scottish Medical Journal, 15, 137.

KOBINGER, W. \& WALLAND, A. (1971) Involvement of adrenergic receptors in central vagus activity. European Journal of Pharmacology, 16, 120.

MacDougall, A.I., Addis, G.J., Mackay, N., Dymock, I.W., TurPIE, A.G.G., Ballingall, D.L.K., MACLennan, W.J., Whiting, B. \& MacARThur, J.G. (1970) Treatment of hypertension with clonidine. British Medical Journal, 3, 440.

McRaven, D.R., Kroetz, F.W., Kioschos, J.M. \& KirkenDALL, W.M. (1971) The effect of clonidine on haemodynamics in hypertensive patients. American Heart Journal, 81, 482.

Muir, A.L., Burton, J.L. \& LAwrie, D.M. (1969) Circulatory effects at rest and exercise of clonidine, an imidazoline derivative with hypotensive properties. Lancet, ii, 181.

Onesti, G., Bock, K.D., Нeimsoth, V., KIM, K.E. \& Merguet, P. (1971) Clonidine: A new antihypertensive agent. American Journal of Cardiology, 28, 74.

Onesti, G., Schwartz, A.B., Kim, K.E., Swartz, C. \& BREST, A.N. (1969) Pharmacodynamic effects of a new antihypertensive drug, Catapres (St-155). Circulation, 39, 219.

Pickering, G. (1968) High Blood Pressure. Churchill: London.

RaFTos, J. (1969) The use of 'Catapres' in the treatment of severe hypertension. Medical Journal of Australia, 2, 684.

Robson, R.D. \& KaPlan, H.R. (1969) An involvement of St 155 [2-(2,6-dichlorophenylamino)-2-imidazoline hydrochloride, Catapresl in cholinergic mechanisms. European Journal of Pharmacology, 5, 328.

Schmitt, H., Schitr, H., Boissier, J.R. \& Giudicelli, J.F. (1967) Centrally mediated decrease in sympathetic tone induced by 2-(2,6-dichlorophenylamino)-2-imidazoline (St-155, Catapresan). European Journal of Pharmacology, 2, 147.

Turnbull, A.C. \& Ahmad, S. (1969) Catapres in the treatment of hypertension in pregnancy-A preliminary study. In: Catapres in Hypertension (Ed. by M. E. Conolly), p. 237. Butterworths: London.

VAamonde, C.A., David, N.J. \& Palmer, R.F. (1971) Hypertensive emergencies. Medical Clinics of North America, 55, 325.

Zaimis, E. \& Hanington, E. (1969) A possible pharmacological approach to migraine. Lancet, ii, 298. 